ment sous l'influence du concentré. Les écarts types résiduels de ces modèles sont assez importants. Ils sont notamment liés à la dispersion des réponses à l'apport de concentré quand celui-ci excède $50 \%$ de la ration, ce qui traduirait une instabilité du milieu ruminal lorsque la proportion de concentré est élevée. La proportion ruminale de propionate semblerait plus importante dans une ration comportant de l'orge $(+0,3 \%$ de propionate $/ \% \mathrm{C}$ ) que dans celle comportant du maïs grain $(+0,22 \%$ de propionate $/ \% C)$. La nature des fourrages influencerait aussi les profils d'acétate et de propionate. En revanche, le $\mathrm{Nl}$ et les interactions $\% \mathrm{C}^{\star} \mathrm{NI}$ ne semblent pas agir.

Cette étude met en avant des variations importantes des profils ruminaux et les régressions proposées permettent une prédiction simple de ces profils.

\section{Macro-mineral and trace-element contents of forages in Réunion island.} G Mandret 1, P Legier 2, F Lanot 1, G Aumont ${ }^{3}$ ( ${ }^{1}$ CIRAD-EMVT, Station CIRAD, Ligne Paradis, 97410 Saint-Pierre, Réunion; 2 CIRAD-CA, Station de la Bretagne, Ligne Paradis, 97400 Saint-Denis, Réunion; 3 INRA, Station de Zootechnie, BP 1232 , 97185 Pointe-à-Pitre Cedex, Guadeloupe (French West Indies))

The objective of this study was to investigate the macro-mineral and trace-element contents of forages in Réunion Island. This country, located in the southern tropical hemisphere, near Madagscar, is volcanic and mountainous (up to $3000 \mathrm{~m}$ ), offering a wide range of pedo-climatic situations. Rainfall is not dependent on altitude and ranges from 750-1000 mm/year on the west coast to $4000-5000 \mathrm{~mm} /$ year on the east coast. Dairy farming fits closely the distribution of temperate forages, while beef farming is carried out on tropical pasture.

Over a 4-year period (1989-1992), phosphorus, calcium, potassium, magnesium, copper, zinc and manganese were determined on 1110 grass samples: temperate: Lolium perenne, L hybridum, L multiflorum, Dactylis glomerata, and Festuca arundinacea; and tropical: Pennisetum clandestinum, $P$ purpureum, Sataria anceps, Chloris gayana, Brachiaria decumbens, $B$ ruziziensis, and $B$ humidicola. Samples were collected in farms, taking into account age of regrowth, type of soil, fertilizers, altitude, climate, location and season. Data were analysed by factorial plus classification procedures on grass samples.

Frequencies of samples with mineral contents lower than the critical nutritional limits for growing cattle according to Underwood (1981) (ie $2.5 \mathrm{~g}$ $\mathrm{Ca} / \mathrm{kg} \mathrm{DM}, 2.0 \mathrm{~g} \mathrm{P} / \mathrm{kg} \mathrm{DM}, 0.87 \mathrm{~g} \mathrm{~K} / \mathrm{kg} \mathrm{DM}, 0.8 \mathrm{~g}$ $\mathrm{Mg} / \mathrm{kg} \mathrm{DM}, 7 \mathrm{mg} \mathrm{Cu} / \mathrm{kg} \mathrm{DM}, 30 \mathrm{mg} \mathrm{Zn/kg} \mathrm{DM}$, $20 \mathrm{mg} \mathrm{Mn} / \mathrm{kg} \mathrm{DM}$ ) were $13.1,25.7,8.6,7.4,62.8$, $41.6,0.7 \%$, for $\mathrm{Ca}, \mathrm{P}, \mathrm{K}, \mathrm{Mg}, \mathrm{Cu}, \mathrm{Zn}$ and $\mathrm{Mn}$, respectively. The classification procedure leads to a 7 -class partition for a within-class inertia/total inertia ratio of $49.1 \%$. These classes of forages differed by the $\mathrm{Ca} / \mathrm{P}$ ratio, the $\mathrm{P}, \mathrm{Cu}$ and $\mathrm{Zn}$ contents, the altitude, the climate, the location, the soil (vertisols vs andosols), and the type of forage (temperate $v s$ tropical forages). These observations suggested $\mathrm{P}, \mathrm{Cu}$ and $\mathrm{Zn}$ deficiencies in Réunion Island.

Further investigations based on blood analyses and clinical observations are now being carried out to confirm the importance of $\mathrm{P}, \mathrm{Cu}, \mathrm{Zn}$ deficiencies according to the different breeding systems and different locations defined by classification in Réunion Island.

\section{Activité ruminale de chèvres laitières pâturant une suberaie emmaquisée. JP Goby, JJ Rochon (Laboratoire des agro- ressources méditerranéennes, université de Perpignan, IUT, chemin de la Passio- Vella, 66025 Perpignan, France)}

L'utilisation de troupeaux caprins laitiers productifs semble être une solution pour concilier les exigences économiques d'un système de production et les contraintes d'entretien du milieu dans des zones méditerannéennes fragilisées par un emmaquisement important, conséquence d'un abandon progressif.

Dans les Pyrénées-Orientales, au piémont du massif des Albères, 50 ha de suberaie emmaquisée par la bruyère arborescentes (Erica arborea) sont intégrés dans le système d'alimentation d'un troupeau de chèvres laitières produisant $800 \mathrm{~kg}$ de lait en $300 \mathrm{j}$ de lactation. Les besoins des animaux sont couverts par un apport de foin et de concentré en bergerie et par $6 \mathrm{~h}$ de pâturage (12 $h-18 h$ ) dans des parcs embroussaillés dont une partie a été améliorée. La composition chimique (en \% de la MS) d'Erica arborea ingérée, estimée par l'analyse d'échantillons prélevés selon 